\title{
CHAPTER 7. A QUESTION OF ATTRIBUTION: THE THEOLOGICAL SIGNIFICANCE OF THE CATENA IN CODEX ZACYNTHIUS (WILliam LAMB)
}

Written by John Moschos around the year 600 AD, The Spiritual Meadow provides a delightful collection of stories about monks and ascetics living in the late sixth and early seventh centuries. Moschos, along with his pupil Sophronius the Sophist, encountered many of these characters in their travels through Syria, Palestine, Sinai and Egypt. While providing a fascinating range of insights into the religious and political complexities of the sixth and seventh centuries, The Spiritual Meadow is not only 'the great masterpiece of Byzantine travel writing': ${ }^{1}$ it also presents another example of a familiar Byzantine literary device, the anthology. Moschos introduces this curious and sometimes humorous account of eccentrics and saints with the words: 'In my opinion, the meadows in spring present a particularly delightful prospect. They display to the beholder a rich diversity of flowers which arrests him with its charm, for it brings delight to his eyes and perfume to his nostrils'. ${ }^{2}$ He goes on to describe the roses, lilies and violets, which he discovers in this imagined meadow: 'From among these I have plucked the finest flowers of the unmown meadow and worked them into a crown which I now offer to you'. With this striking image, Moschos invites the reader 'to think of this present work in the same way'. While a spray of flowers may bring delight to the recipient, Moschos intended this collection of stories to excite a life of virtue and piety in the reader.

The work of John Moschos is a suitable starting point for considering the theological significance of the catena in Codex Zacynthius: first, his work provides a fitting backdrop to the period in which the catena was compiled. Secondly, while admittedly his work is not a collection of extracts from existing authorities, characteristic of a catena or a florilegium, his words alert us to the etymological significance of the Greek word from which the English word 'anthology' is derived. Thirdly, although a 'meadow' presents the reader with a rather irenic and charming scene, we should not ignore the fact that the

\footnotetext{
${ }^{1}$ William Dalrymple, From the Holy Mountain: A Journey in the Shadow of Byzantium (London: Harper Press, 1997), 3.

${ }^{2}$ John Moschos, The Spiritual Meadow, trans. John Wortley (Kalamazoo: Cistercian Publications, 1992), 3.
} 
stories which Moschos recounts and the period in which he lived betray the marks of the Christological controversies which continued to rage during the sixth and seventh centuries. We can see evidence of this discord in the numerous references in The Spiritual Meadow to the 'Severan sect', i.e. those who followed Severus of Antioch. ${ }^{3}$ The fact that members of the Chalcedonian, imperial state church referred to 'anti-Chalcedonians' as members of the 'Severan sect' is perhaps a measure of the extent to which Severus had come to be feared and despised. In his account of the life of Theophanes, John Moschos describes Theophanes, a Nestorian monk, who sought guidance from the great elder, Kyriakos. Hearing that he was a Nestorian, Kyriakos was concerned for the man's soul and impressed upon him the importance of believing that 'the holy Virgin Mary' was in truth 'the Mother of God' (Theotokos) for this was the only way to salvation. When the brother said that 'all the sects speak like that' and as a simple soul he had no way of knowing where the truth lay, he asked for a vision. Eventually he was taken to a cave by the Dead Sea where the elder showed the brother a vision of 'a dark and disagreeable place where there was fire - and showed him Nestorius, Theodore, Eutyches, Apollinarius, Evagrius and Didymus, Dioscorus and Severus, Arius and Origen and some others, there in that fire'. The brother was told: 'This place is prepared for heretics and for those who blaspheme against the Holy Mother of God and for those who follow their teachings' . ${ }^{4}$ For John Moschos at least, there was no ambiguity about the reputation of Severus of Antioch. The lines between 'orthodox' and 'heretic' were sharply and clearly drawn.

There is a striking contrast between John Moschos' rather unsympathetic description of the 'Severan sect' and the correspondence that we find recorded in the preface at the beginning of the Catena in Lucam in Codex Zacynthius. ' The compilation includes a remarkable reference to Cyril of Alexandria's Letter to Eulogius: 'One ought not to avoid and refuse everything which heretics say. For they grant many things which we also grant' (preface, lines 8-9). The compiler, who uses the first person singular ( $\pi \varepsilon \pi$ oi $\eta \kappa \alpha$, line 6), begins by remarking that those who encounter this particular volume should know that it comes from many works of holy and orthodox fathers, and also from 'discredited exegetes' ( $\dot{\delta} \delta \circ x i \mu \omega \nu) \dot{\xi} \xi \eta \gamma \eta \tau \tilde{\omega} \nu)$. While the compiler acknowledges that there may be material which

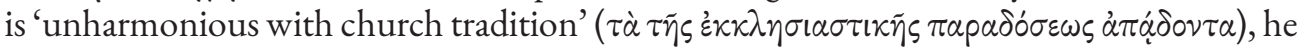
includes a quotation from Cyril of Alexandria in order to make it clear to the reader that there may be some value in the things which those regarded as heretics have to say. ${ }^{6}$

\footnotetext{
${ }^{3}$ The followers of 'Severus', the 'Severans' or the 'Severites' are described in a number of passages: Moschos, The Spiritual Meadow, 20-21, 39, 63-64, 85, 161, 191.

${ }^{4}$ Moschos, The Spiritual Meadow, 18.

${ }^{5}$ For more on the preface, see pages $67-8$.

${ }^{6}$ It is worth noting that Jerome, in his Letter to Tranquillinus, makes very similar comments in responding to his correspondent's concerns about reading Origen and those whose orthodoxy had become suspect: 'You ask me, insignificant though I am, for an opinion as to the advisability of reading Origen's works. Are we, you say, to reject him altogether with our brother Faustinus, or are we, as others tell us, to read him in part? My opinion is that we should sometimes read him for his learning just as we read Tertullian, Novatus, Arnobius, Apollinarius and some other church writers both Greek and Latin, and that we should select what is good and avoid what is bad in their writings
} 
It is perhaps significant that we find this same preface elsewhere within the manuscript tradition. ${ }^{7}$ It is connected with Matthew's Gospel, with John's Gospel, and more commonly with Luke's Gospel. While it is tempting to assert that the more common association with Luke suggests that this preface belongs to the compilation of catenae on Luke, such a proposal remains tentative given the paucity of evidence available. Nevertheless, whatever their provenance, these words certainly serve to illuminate our reading of the material within this particular catena.

There are over 300 scholia in the margins of the undertext of Codex Zacynthius. Just over ten per cent are unattributed (or at least attributed to 'an unattributed source'), while the others are attributed to Cyril of Alexandria, Origen, Titus of Bostra, Severus of Antioch, Victor the Presbyter, John Chrysostom, Eusebius of Caesarea, Isidore of Pelusium, Basil of Caesarea and Apollinarius. ${ }^{8}$ When we consider John Moschos' list of heretics burning in the fire, it is perhaps noteworthy that Origen and Severus are two of the most prominent authorities in the catena of Codex Zacynthius.

The fact that a catena can include material from writers like Apollinarius, Origen and Severus of Antioch has long fascinated commentators. Robert Devreesse suggested that the inclusion of material from figures deemed heretical within the imperial state church reflects the 'liberal spirit' of the Greek catenae.' The quotation from Cyril's Letter to Eulogius would only serve to confirm that catena compilers regarded writers like Origen, Apollinarius and Severus as heretical. While they might hesitate to accept the Christological formulations of these writers, they were content to accept and include aspects of their exegesis.

This 'liberal spirit' has served to reinforce a dominant perspective in recent scholarship, which has tended to emphasise the 'doctrinal neutrality' of catenae. Manlio Simonetti speaks of the 'progressive sterility' of catenae. ${ }^{10}$ The compilers of catenae were so fearful of straying into the doctrinal controversies of previous centuries that they were content simply to repeat the teachings of the fathers. Evidence of their neutrality is

according to the words of the Apostle, "Prove all things: hold fast that which is good".' (Jerome, Epistula 62.2).

${ }^{7}$ See also the discussion on page 67 above. We also find evidence of this preface in the fourteenthcentury manuscript, Oxford, Bodleian Library, Selden Supra 29 (GA 54), on folios 115-115v. The material is placed immediately before an excerpt of Titus of Bostra on Luke's Gospel, alongside a number of other sources, before the Gospel of Luke begins on folio 120. Similarly, a fragment from this preface occurs in the tenth-century manuscript, Oxford, Bodleian Library, Cromwell 15 (GA 527), on folio 112. This is followed by a couple of extracts from John Chrysostom and others before the Gospel of Luke begins (ff. 116-174).

${ }^{8}$ See Chapters 5 and 6.

${ }^{9}$ Robert Devreesse, Les anciens commentateurs grecs de l'Octateuque et des Rois: fragments tirés des chaînes (Vatican City: Biblioteca Apostolica Vaticana, 1959), viii.

${ }^{10}$ Manlio Simonetti, Biblical Interpretation in the Early Church: An Historical Introduction to Patristic Exegesis, trans. John A. Hughes (Edinburgh: T\&T Clark, 1994), 111. 
adduced in the comprehensive range of different sources from Philo of Alexandria to Severus of Antioch. In his study of Procopius of Gaza (often associated with the origins of catenae), Bas ter Haar Romeny notes that the choice of sources and the comparison between the full commentaries and the fragments chosen offer some insight into 'the kind of exegesis Procopius and his predecessors were interested in'. ${ }^{11}$ Procopius' choice of 'Antiochene' exegetes alongside 'Alexandrians' suggests that 'the different schools of exegesis were treated equally, and that doctrinal issues played no role. ${ }^{12}$ Ter Haar Romeny reinforces this perspective of 'doctrinal neutrality' when he offers the following comment:

The catenists and Procopius were mostly interested in the solution of problems and questions posed by the text:... There is hardly room for the philosophical, spiritual, and doctrinal here. As Petit remarks, on the basis of the Catena on the Octatench one would not suspect that the majority of the exegetes quoted were involved in the Trinitarian and Christological debates of their era. ${ }^{13}$

However, one of the fascinating things about Codex Zacynthius is the fact that a number of voices, particularly those associated with 'Antiochene' patterns of exegesis, are completely missing from this particular anthology. While in other catenae on Luke's gospel, we find material from writers such as Theodore of Mopsuestia and Theodoret of Cyrrhus, they do not feature in Codex Zacynthius. Moreover, as Harold Greenlee points out, 'the title $\ddot{\alpha} \gamma$ ros is applied regularly to John, Basil, Cyril, and Titus, and sometimes to Severus. ${ }^{14}$ Greenlee remarks that 'since Severus was declared a heretic, it may seem strange that he is sometimes designated "Saint"; and the fact that he is so designated regularly (with one exception) in the second half of the existing portions of the catena and not at all in the first half may seem stranger still. Severus is usually designated "Archbishop of Antioch," although a few times merely "of Antioch" and sometimes without any title. ${ }^{15}$ Although it is possible that this is the careless attribution of a copyist, the description of Severus as aylos appears to suggest that not all those responsible for producing this catena regarded him as heretical. ${ }^{16}$

${ }^{11}$ Bas ter Haar Romeny, 'Procopius of Gaza and his Library,' in From Rome to Constantinople ed. Hagit Amirav and Bas ter Haar Romeny (Louvain: Peeters, 2007), 173-90, here 189.

${ }^{12}$ Ter Haar Romeny, 'Procopius of Gaza and his Library,' 189.

${ }^{13}$ Ter Haar Romeny, 'Procopius of Gaza and his Library,' 189 . .

${ }^{14}$ J. H. Greenlee, 'Codex Zacynthius: The Catena and the Text of Luke' (pages 281-99 of the present volume).

${ }^{15}$ Page 288 below (see also page 65). Greenlee notes that Tregelles had raised the possibility, and Hatch had advanced as a definite theory, the idea that the name of Severus had been erased soon after the manuscript was written. They had speculated that the document had been written during the lifetime of Severus, before the edict of Justinian in 536 which ordered his writings to be burned and that the owner of the manuscript erased the name of Severus soon after the edict was issued in order to protect himself and the manuscript. However, neither Greenlee nor the Codex Zacynthius Project has detected any evidence that any names have been erased, other than as 'part of the erasure of the entire manuscript after several centuries of use' (p. 289 below; see also p. 114).

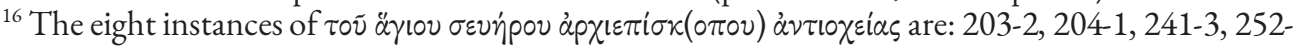
2, 260-3, 268-3, 300-1, 301-1. 
The evidence of these marginal comments provokes a number of questions which require further exploration: what does the pattern of selection and attribution tell us about the compiler's understanding of the authoritative status of their sources? Does the material contained within the catena of Codex Zacynthius betray a 'liberal spirit', as Devreesse suggests? Or does the material, particularly the material relating to Severus of Antioch, provide evidence of a more distinctive theological and ideological perspective?

\section{AUTHORITY, ATTRIBUTION AND ANONYMITY}

In 'Scholiasts and Commentators', Nigel Wilson notes that one of the distinctive characteristics of catenae is that 'it is very common to cite at the beginning of each excerpt the name of the author from whose work it is taken' ${ }^{17}$ Wilson suggests that biblical scholars made this innovation, in contrast to the anonymity which characterises the scholia of classical tradition, because they wished to be 'precise in these matters, especially as the orthodoxy of individual authors might be questioned'. ${ }^{18}$ This insight is shared with the editors of a more recent collection of essays in the volume, On Good Authority. Noting that 'respect for authoritative voices is sometimes considered an essential characteristic of all premodern intellectual activity', they recognise that this phenomenon is not as uniform as it might seem at first glance. ${ }^{19}$ The essays in this volume deal with 'the questions of how texts attempt to gain authority and if so how they use-or abuse-earlier writings in the construction of their own authority.' ${ }^{20}$ They give special attention to compilations and anthologies. They note that 'a first and rather self-evident aspect related to the authority of a certain literary work is its authorship. Quite often it is the name of an author that provides a work with an authoritative status'. ${ }^{21}$ Similarly, they suggest that 'it is the denial of an author's involvement in a text that deprives it of this status'. ${ }^{22}$ Certainly, modern scholarship betrays a preoccupation with the identification of authors of anonymous works, and we might well conclude from the fact that so many scholia in the biblical catenae are introduced with a citation naming the author that ancient editors were also concerned to identify their sources with a certain degree of precision. ${ }^{23}$ Ceulemans

\footnotetext{
${ }^{17}$ Nigel G. Wilson, 'Scholiasts and Commentators,' GRBS 47 (2007): 39-70, here 47.

${ }^{18}$ Wilson, 'Scholiasts and Commentators', 47.

${ }^{19}$ Reinhart Ceulemans and Pieter De Leemans, ed., On Good Authority: Tradition, Compilation and the Construction of Authority in Literature from Antiquity to the Renaissance (Turnhout: Brepols, 2015), 11.

${ }^{20}$ Ceulemans and De Leemans, On Good Authority, 11.

${ }^{21}$ Ceulemans and De Leemans, On Good Authority, 12.

${ }^{22}$ Ceulemans and De Leemans, On Good Authority, 12.

${ }^{23}$ Of course, there are instances where authors are misattributed in the tradition. In the course of comparing various citations in the Patrologia Graeca, one may discover relatively frequently that a passage attributed to Origen in one fragment is attributed to Cyril of Alexandria in another. Indeed, it is not uncommon in ancient literature to discover that a text has been wrongly attributed to an authoritative voice retrospectively. I am grateful for the observations about pseudepigrapha in
} 
and De Leemans contend that the identification of 'an author in the manuscripts undoubtedly influences the authoritative level of the text and consequently also its transmission'. ${ }^{24}$ The attribution makes a difference to the way in which the reader pays attention to it. Thus, although on the first fourteen occasions Severus is mentioned he is given a simple introduction, when he is referred to as $\ddot{\alpha} \gamma 105$ in eight out of the nine subsequent occasions that he is cited, we begin to pay attention to his words in a more acute way. His authority has been given greater weight.

Ceulemans and De Leemans argue that in reading these texts, we need to pay attention to the importance of tradition: 'Authors were expected to reckon with and to respect earlier voices since they were considered not only informative but in some cases even normative'. ${ }^{25}$ The appeal to established earlier voices served to increase the text's authority. ${ }^{26}$ For Ceulemans and De Leemans, any form of anthology or compilation literature plays a part 'not only in transmitting authoritative voices but also in shaping them'. ${ }^{27}$

While these more general comments about the use of anthology present a number of resonances with the way in which sources are used in biblical catenae, these observations provoke a number of questions in relation to Codex Zacynthius: first, a significant number of the scholia contained in Codex Zacynthius are recorded as unattributed: $\dot{\xi} \xi$ aे $v \pi i \gamma p \alpha \dot{\varphi} \varphi{ }^{28}$. ${ }^{28}$ This seems to be at odds with the practice of quoting established authorities. Secondly, we need to consider the fact that while tradition may be important, a tradition can also embody an ongoing argument. We need to interrogate carefully the use of the word 'normative' in relation to a tradition, particularly if that tradition, in the words of Alasdair MacIntyre, embodies 'continuities of conflict'. ${ }^{29}$

As part of this project, we have been industrious in identifying this unattributed material, but why was this material anonymised in the first place? Given that many scholars infer from the use of these attributions that the compilers of the catenae were seeking to offer some assurances about the provenance and authority of these extracts, one might conclude that the process of anonymising these texts is driven by a desire to conceal their more heterodox origins. This is certainly the argument presented by Peter

Hindy Najman, Losing the Temple and Recovering the Future: An Analysis of 4 Ezra (Cambridge: CUP, 2014).

${ }^{24}$ Ceulemans and De Leemans, On Good Authority, 12.

${ }^{25}$ Ceulemans and De Leemans, On Good Authority, 13.

${ }^{26}$ In some cases, the selection of excerpts from earlier sources aimed at enhancing the authority of the author or compiler. In other cases, the authority of a compiler is completely secondary to the selection of excerpts from earlier sources. The anthology derives its authority not so much from itself but from the reputation of the authors and texts being quoted.

${ }^{27}$ Ceulemans and De Leemans, On Good Authority, 15.

${ }^{28}$ See also page 100 above.

29 'Traditions, when vital, embody continuities of conflict' (Alasdair MacIntyre, After Virtue [London: Duckworth, 1981], 221); quoted in the frontispiece of Rowan Williams, Arius: Heresy and Tradition (London: Darton, Longman and Todd, 1987). 
Tzamalikos, in a recent study of the Scholia in Apocalypsin, ${ }^{30}$ which he places amidst the tensions between imperial Christian orthodoxy and certain monastic circles in the sixth century. Tzamalikos argues that the reason the scholia on the book of Revelation are anonymised was precisely to ensure that the comments did not provoke the scrutiny of their detractors. ${ }^{31} \mathrm{He}$ asserts that the scholia conceal elements of monastic dissent, subverting the authority of the imperial state church.

We might imagine that the process of anonymising these texts serves a similar function in Codex Zacynthius. Certainly, in the case of a couple of unattributed passages (014-1 and 076-1), the 'new' or 'different' nature attributed to Christ betrays a Christological perspective which is at odds with the 'two natures' embraced by the Council of Chalcedon. And yet, the majority of the comments under the heading $\dot{\varepsilon} \xi$ aे $\varepsilon \pi \iota \gamma \rho \dot{\alpha} \varphi \circ v$ are neither controversial in terms of content nor remarkable in terms of attribution. Our research reveals that most of the material comes from the following writers: Origen, Cyril of Alexandria, Eusebius of Caesarea, and Titus of Bostra (see Table 6.1). A number of scholia remain anonymous, and it is possible that, like 014-1 and 0761 , this material is drawn from more heterodox sources. Nevertheless, it is striking that these anonymised sources mirror almost exactly the named sources within the catena.

The fact that this material is unattributed may not be a result of a deliberate editorial policy by the editor to anonymise material. It may be that along with the attributed material, one of the sources which the compiler drew on was an existing anonymised catena. Given that it was common for scholia to be assembled without attribution, it may be that this earlier anthology simply adopted the broader convention of the commentators of the time. But it does not necessarily follow that we should infer that a source comes from a dissenting voice simply because it is anonymous. As recent work on anonymity and pseudonymity suggests, the concealment of an author's identity does not necessarily betray some embarrassment or diffidence about the text's authority. In some cases, uncertainty about authorship can give a work of literature 'a special voltage'. ${ }^{32}$ In Author Unknown: The Power of Anonymity in Ancient Rome, Tom Geue suggests that scholars, hardwired by the conventions of historicism to identify the authorship and context of individual works, are not always alert to the impact of texts which have been anonymised.

${ }^{30}$ P. Tzamalikos, An Ancient Commentary on the Book of Revelation: A Critical Edition of the Scholia in Apocalypsin (Cambridge: CUP, 2013).

31 'These scholia are mostly extensive quotations from Didymus' lost Commentary on the Apocalypse, and in the second place quotations from Theodoret and Clement of Alexandria. None of these persons was a darling to the imperial cliques of the mid-sixth century. To the orthodox, the authors on which the compiler (as well as author) Cassian draws are mostly either condemned or suspicious or distrustful. This is why Cassian left these Scholia without attribution, yet he was himself aware of their spiritual origin.' P. Tzamalikos, The Real Cassian Revisited (Leiden: Brill, 2014), 287-8.

${ }^{32}$ John Mullan, Anonymity: A Secret History of English Literature (London: Faber \& Faber, 2007), 7. 
He argues that anonymity is not a problem to be solved. It is simply one of the effects of the text which we need to take seriously. Moreover, while we are acculturated 'to thinking about authority as a property of names', Geue argues that 'there is an equally trenchant authority to namelessness. ${ }^{33}$ Anonymity may serve to 'universalise' the text. The text may be furnished with an impersonality which 'seems to kit the text out for use as something transpersonal: ... an authoritative bearer of witness to something bigger than itself ${ }^{34}$ Alternatively, the process of anonymisation may permit the compiler of the catena to select and coordinate a vast array of different texts and sources into a 'reauthored' running commentary. ${ }^{35}$ Given that within the tradition there are catenae which are anonymised, these observations help us to see that both attribution and anonymity can serve to accentuate the 'authority' of the text. Nevertheless, it is curious that the catena in Codex Zacynthius appears to use both attribution and anonymity within the same text. There is a curious precision about the phrase $\dot{\varepsilon}_{\xi} \dot{\alpha} \nu \varepsilon \pi \iota \gamma p \dot{\alpha} \varphi$ ov in attributing the material to an 'unattributed' source. The fact that in other places material is attributed not just to the author but also to specific works within the corpus of the author betrays a rather careful and cautious approach to the question of attribution. The catena in Codex Zacynthius shows its workings with a patient and persistent determination.

\section{A 'LibERAL SPIRIT'?}

The selection of sources within the catena of Codex Zacynthius draws heavily on Cyril of Alexandria, Origen, Titus of Bostra and Severus of Antioch. There are also shorter extracts from John Chrysostom, Apollinarius, Eusebius, Basil of Caesarea, Victor the Presbyter and Isidore of Pelusium. Intriguingly, three of the passages attributed to Isidore of Pelusium are attributed specifically to Letters 48,363 and $1759 .{ }^{36}$ Similarly, passages attributed to Severus of Antioch are attributed with great precision. There are extracts from a series of his homilies: 2, 32, 33, 36, 51, 63, 82, 89, 113, 115, and 118 . There is reference to a commentary on the Book of Numbers. There are quotations from his correspondence: an extract from a letter to Caesaria the Noblewoman on the topic of Christ's circumcision, an extract from a letter to Sergius the Chief Physician, a couple of extracts from a letter to Anastasia the Deacon, as well as an encyclical letter to Kyriakos and the Bishops. There are elements from his more polemical writings, including a tract 'Against the Testament of Lampetius', a tract 'Against the Apology of Julian', and an 'Apology of Philalethes'. There is also one passage attributed by the catenist to one of Severus' homilies which appears in fact to come from Cyril of Alexandria (301-1). ${ }^{37}$

While much of this material attributed to Severus may also be found in the Patrologia Orientalis, the distinguishing characteristic of the material in Codex Zacynthius is that it

\footnotetext{
${ }_{33}$ Tom Geue, Author Unknown: The Power of Anonymity in Ancient Rome (London: Harvard University Press, 2019), 16.

${ }^{34}$ Geue, Author Unknown, 16.

${ }^{35}$ Note Marie-Dominique Chenu's comment that the Catena aurea constitutes a 'concatenation of patristic texts cleverly coordinated into a running commentary' (M.-D. Chenu, Introduction à l'étude de St. Thomas d'Aquin (Paris: Vrin, 1974), 279-80).

${ }^{36}$ See p. 106 above.

${ }^{37}$ See also p. 115 above.
} 
is written in Greek. This is striking because most of his writings have come down to us in Syriac and Coptic. One significant reason for this is that in the year 536, the Emperor Justinian had issued an edict that all the works of Severus should be burned. Severus, who had become a leading anti-Chalcedonian voice in his unwavering commitment to promote Cyril of Alexandria's Christology, had already been driven into exile in 518 by the Emperor Justin. This was largely due to the lobbying of his nephew, Justinian. At his accession in 527, Justinian sought to resolve the disputes that had emerged in the East following the Council of Chalcedon. Eventually, after tortuous negotiations and debates, he came down firmly on the Chalcedonian side.

In Exegesis and Empire in the Early Byzantine Mediterranean, Michael Maas argued persuasively that from the beginning of the sixth century, biblical exegesis became increasingly a matter of imperial interest. Explaining why a senior legal officer of the Emperor Justinian, Junillus Africanus, should take time to write the Instituta Regularia ${ }^{38}$ and issue guidance about biblical interpretation, Maas suggests that: 'In the theological hothouse of Justinian's Mediterranean, biblical exegesis carried significant political force'. ${ }^{39}$ Maas shares with Manlio Simonetti the sense that the enterprise of biblical interpretation had become more pedestrian during the sixth century in the light of the Christological controversies of late antiquity. Where they differ is that while Simonetti seems to imply that this was a consequence of intellectual indolence, Maas argues that the Emperor Justinian attempted to impose his own limits and constraints on those engaged in the interpretation of Scripture. He achieved this in a number of ways: first, by defining the limits of orthodoxy; secondly, by ensuring that the officials of his court conformed with the emperor's definition of faith; and thirdly, by initiating a number of reforms of the education system and placing restrictions on those who were allowed to teach. It is perhaps remarkable that the contents of this catena provide some evidence of dissent from these strictures of imperial orthodoxy. Indeed, with so many scholia from Cyril of Alexandria and comments from Severus, which have a bearing on Christological questions, it is arguable whether the contents are consistent with a spirit of 'doctrinal neutrality'.

In a fascinating article, Yonatan Moss notes the fact that while much of Severus' writings can be found in Syriac and Coptic, one can find quotations of his writings in Greek among many of his critics and detractors in the sixth and seventh centuries. ${ }^{40}$ One can also find extracts from his works in the catenae of the Old and New Testaments. In spite of what Moss calls 'Justinian's harsh and unequivocal decree' (p. 788), this material is extensive. Karl Staab was the first to note the curious presence of Severus' writings in the

\footnotetext{
${ }^{38}$ English translation: 'The Handbook of the Basic Principles of Divine Law'.

${ }^{39}$ Michael Maas, Exegesis and Empire in the Early Byzantine Mediterranean: Junillus Africanus and the Instituta Regularia Divinae Legis (Tübingen: Mohr Siebeck, 2003), 112.

${ }^{40}$ Yonatan Moss, 'Saving Severus: How Severus of Antioch's Writings Survived in Greek,' GRBS 56 (2016), 785-808.
} 
catenae on the Catholic epistles: ${ }^{41}$ 'With the exception of John Chrysostom and Cyril of Alexandria, Severus is quoted in the catenae on the Catholic Epistles more than any other Church father'. ${ }^{42}$ As an intriguing contrast, the catenae on the Pauline epistles contain almost nothing from Severus. Françoise Petit notes that in the earliest recension of the catenae on the Octateuch there is no evidence of Severus' writings, but she suggests that a later branch of the tradition, possibly after Severus' death in 538, 'was expanded to include a host of scholia culled from the works of Severus'. ${ }^{43}$ While Moss notes Devreesse's suggestion that the inclusion of Severan material could reflect the 'liberal spirit' of the catenae, he suggests that this neat ecumenical solution does not satisfactorily address three significant difficulties: first, there is the simple fact of Justinian's decree; how did people have access to Severus' works given the ban? Tregelles had attempted to address this question by suggesting that the material had been compiled before the ban, a view endorsed by Hatch. Secondly, Moss notes that, in describing the catena on Isaiah, Devreese observes that most of the ninety-seven scholia attributed to Severus are

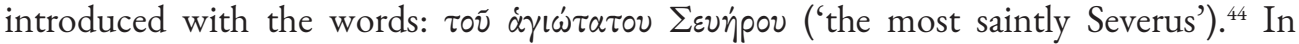
addition, we see references to Severus in the Catena on Acts, published by John Cramer and drawing on the twelfth-century manuscript Oxford, New College 58 (GA 2818). An

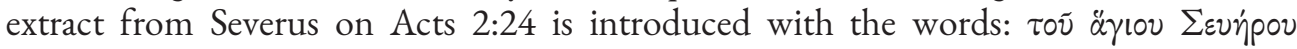

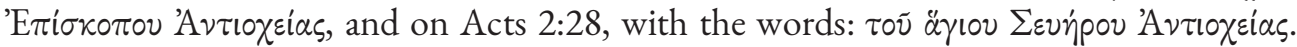
Moss was not aware of the material in Codex Zacynthius, but his question applies with exactly the same force: why do these Byzantine scribes refer to Severus in this way? The third difficulty is the disproportionately large place given to Severus in many catenae. Moss notes that material from Severus is often extensive, and that these passages are regularly introduced with a precise reference to where exactly in Severus' writings they might be found. Again, we find this phenomenon in Codex Zacynthius. Moss seeks to address these difficulties by proposing a slightly different solution: he says that the inclusion of this material from Severus, rather than being the work of a group of liberally minded Chalcedonian editors, as Devreesse would suggest, was in fact the work of a group of anti-Chalcedonian editors, who sought to take advantage of the 'liberal spirit' of the catenae, by inserting as many of Severus' writings as they could include:

Fearing, after Justinian's novella of 536, that their master's works faced extinction, Severus' adherents attempted to save what they could by incorporating selections from the corpus into an already existing framework. It is possible that they operated in Egypt, where much of the early work on the catenae is thought by some scholars to have taken place, and where imperial persecution of anti-Chalcedonians had historically been less severe. ${ }^{45}$

\footnotetext{
${ }^{41}$ Karl Staab, 'Die griechischen Katenenkommentare zu den Katholischen Briefen,' Biblica 5 (1924): 296-353.

${ }^{42}$ Moss, 'Saving Severus,' 791.

${ }^{43}$ Cited in Moss, 'Saving Severus,' 791.

${ }^{44}$ Robert Devreesse, 'Chaînes exégétiques grecques,' in Dictionnaire de la Bible: Supplément (ed.

A. Pirot. Paris: Letouzey et Ané, 1928), 1151, quoted by Moss, 'Saving Severus,' 795.

${ }^{45}$ Moss, 'Saving Severus', 798.
} 
In Moss's view, these anti-Chalcedonian editors took advantage of the 'ecumenical character' of catenae in order to preserve material from Severus of Antioch.

It is an ingenious proposal, and it serves to explain both the reverence shown to Severus and the detailed attribution of sources. And yet, Moss' proposal takes Justinian's condemnation of Severus and the banning of his books as the final word on the rather vexatious Christological controversy which had rumbled on for the first four decades of the sixth century. Codex Zacynthius, like other catenae, also contains a number of scholia from Origen, whose writings were also condemned by Justinian at some point between 536 and 543. Moss does not consider the inclusion of material from Origen in the catenae of the Old and New Testaments, but this evidence may help us to consider the merits of the hypothesis he presents.

The truth is that, in spite of these condemnations, attempts to court the adherence of members of the miaphysite party continued during Justinian's reign up until and then beyond the Second Council of Constantinople in 553. One of the curious innovations of Justinian's reign was to handle theological controversy by anathematising theologians and biblical commentators who were already dead. Origen of Alexandria has the dubious privilege of already belonging to this number but, at some point in the winter of 544, Justinian provoked the Three Chapters Controversy by condemning the works of three leading fifth-century theologians, who had influenced Nestorius: Theodore of Mopsuestia (c.350-428), Theodoret of Cyrrhus (c.393-c.468), and Ibas of Essa (d.457). This innovation was the source of some discomfort and disturbance in some parts of the empire because it appeared to undermine the Council of Chalcedon, which had exonerated Theodoret and Ibas. Moreover, it also appeared to undermine a basic principle that you only anathematized those who were able to recant. The Three Chapters Controversy suggests that Justinian had not completely given up on resolving the differences between Chalcedonians and anti-Chalcedonians after the condemnation of Severus in 536. Moreover, it is perhaps striking that whereas Theodore of Mopsuestia and Theodoret of Cyrrhus are quoted extensively in some of the other catenae on the New Testament, they are nowhere to be found in Codex Zacynthius.

Does this suggest that the material within the margins betrays a more antiChalcedonian emphasis? Or, in the omission of Theodore and Theodoret, can we detect the influence of the deliberations of the Second Council of Constantinople in 553? We need to take some care in drawing conclusions from the admittedly partial evidence provided by the comments on portions of the first eleven chapters of Luke's gospel. Nevertheless, the fact that these chapters include Luke's infancy narratives, the account of the temptation, the beginning of Jesus' public ministry, various healings, miracles and exorcisms, the Sermon on the Plain, and the Transfiguration, there is probably sufficient material to assess whether we can detect the presence of the ongoing Christological controversies of the sixth and seventh centuries.

Certainly, the material within the catena emphasises the unity of the identity of Jesus Christ, in a way which is entirely consistent with Cyril of Alexandria's Christology. Severus and others were loyal adherents of Cyril and they sought to conserve and protect 
his inheritance. Indeed, we should not underestimate the influence of Cyril. He is far and away the most dominant voice among the scholia conserved within the Codex Zacynthius. ${ }^{46}$ We see clear examples of this emphasis on the unity of Christ's identity in a range of sources, e.g. Cyril of Alexandria (114-1), Severus of Antioch (005-5), one of the 'unattributed' scholia elsewhere identified as Origen (044-1), and Victor the Presbyter (0521). It is a perspective which is emphasised again and again in the consistent use of the term 'Theotokos' or 'God-bearer' to describe Mary. In an early extract, Severus of Antioch refers to Mary as 'the holy God-bearer (Theotokos) and ever-virgin Mary' (005-5). At the Visitation, when Elizabeth says 'Why has this happened to me, that the mother of my Lord comes to me?' (Luke 1:43), the catenist includes an 'unattributed' scholium (045-1), elsewhere assigned to Origen: Elizabeth says that she 'is unworthy of the presence of the God-bearing Virgin'. A little later, Severus describes Elizabeth as 'the relative of Mary the God-bearer' (038-3). ${ }^{47}$ Subsequent examples show a preponderance of passages from Origen. Even though Origen himself had become the subject of some suspicion by the middle of the sixth century, the use of this term was endorsed by the Second Council of Constantinople and its adoption was seen as something of a victory for the miaphysite party.

At the same time, other extracts emphasise that Christ is both fully human and fully divine. Commenting on Luke's reference to 'servants of the Word' (Luke 1:2), the passage from Severus of Antioch avoids the language of a single $\varphi \dot{v} \sigma \iota \zeta$, emphasising the unity of humanity and divinity in a single $\dot{\tau} \pi \dot{\sigma} \sigma \alpha \sigma \iota \varsigma$. Nevertheless, there is also perhaps a studious avoidance of the language of 'two natures', the touchstone of Chalcedonian orthodoxy. While there is no ambiguity about the idea that Christ was both fully human and fully divine, the real area of contention between Chalcedonians and anti-Chalcedonians lay in spelling out exactly how this was so. In one 'unattributed' scholium (014-1), the commentator contemplates the miraculous birth of Christ: in the Virgin birth, 'there was the introduction of a totally new nature which did not exist previously. ${ }^{48}$ In another scholium, again 'unattributed', on Luke 2:6, the writer-who appears to be Cyril of Alexandria-suggests that Christ' is different in respect of his nature from those who are throughout the inhabited world' (076-1). The inference is that Christ was incarnate in one nature.

While the miaphysite sympathies of these passages are evident, it is also worth noting that there is a curious absence of any polemic directed towards the defenders of Chalcedon. Commenting on Luke's description of the Presentation, when Simeon remarks that 'This child is destined for the falling and the rising of many in Israel, and to be a sign that will be opposed' (Luke 2:34), the catena includes a scholium from Basil of Caesarea's Letter to Bishop Optimus (086-1), which refers directly to the controversies surrounding the doctrine of the incarnation:

\footnotetext{
${ }^{46}$ See Tables 5.2 and 6.1, and note also the comments about Cyril's biblical text on page 53.

${ }^{47}$ Further examples of the use of the term 'Theotokos' include: 044-3 (Origen), 045-1 (Origen), 081-2 (possibly Origen), 083-2 (Severus).

${ }^{48}$ It is possible that the same sentiment is expressed, albeit in a more abbreviated form in an extract from Eusebius of Caesarea (038-1).
} 
They do not cease quarreling about the incarnation of the Lord: some assert that the body was assumed, and others that his dwelling here was bodiless; some claim that his body could experience suffering, and others that in some way an illusion fulfilled the bodily dispensation; others still say that the body was earthly, and others that it was heavenly; some say that he existed before time began, while others say that he took his beginning from Mary. For this reason, he is 'a sign that will be opposed' (Luke 2:34).

The passage condemns some of the earlier Christological heresies, such as Docetism and Adoptionism, but there is nothing here that would cause a defender of Chalcedon to dissent. At the same time, it is intriguing to note that the reference to 'an illusion' $\left(\varphi \alpha \nu \tau \alpha \sigma^{\prime} \alpha\right)$ echoes an earlier scholium in the catena in which Severus of Antioch refutes 'the objectionable belief of Eutyches' (044-4) and his invention of 'the appearance of some non-existent phantasm' $(\varphi \alpha \dot{\nu} \tau \alpha \sigma \mu \alpha)$. Eutychianism, which had been so roundly condemned at the Council of Chalcedon, is dismissed in no uncertain terms. Nevertheless, with perhaps the exception of these two passages, in contrast to the more uncompromising and polemical views of John Moschos, the scholia selected in Codex Zacynthius tend to present a rather more irenic and conciliatory tone.

Much of the material in the catena is consistent with the settlement characteristic of the Second Council of Constantinople in 553. It embraces the title 'Theotokos' for Mary. It omits the writings of Theodore and Theodoret, which had been condemned at the Council. It also emphasises the essential unity of the person of Christ. But the truth is that the measures introduced by Justinian did not bring the resolution he so desired. Christological controversies continued with just as much enthusiasm after 553. Justinian's attempt to find some accommodation between the two sides had failed. By the beginning of the seventh century, in the face of internal political and external military threats, there were renewed efforts by the Emperor Heraclius (6I0-64I), under the guidance of Sergius, the Patriarch of Constantinople, to see if these differences might be resolved. ${ }^{49}$ Recognising that previous attempts at compromise had foundered on the language of

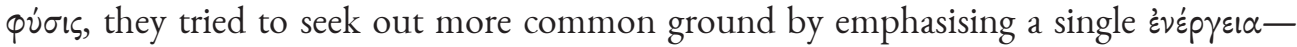
'energy', 'operation' or 'activity' - in order to describe Christ's divine agency.

The emperor and the patriarch of Constantinople sought to achieve what had so far proved to be 'an elusive doctrinal consensus' 50 by promoting the doctrine of 'Monenergism'. They sought 'to reconcile the supporters and the adversaries of Chalcedon on the basis of the formula two natures-one activity (energeia)'. ${ }^{1}$ Cyril Hovorun has argued that this 'Monenergism' owed much to the theological legacy of Severus of Antioch. He argues that 'Severus was first among the principal teachers of anti-

${ }^{49}$ For a detailed account of the challenges faced by Heraclius, see C. Hovorun, Will, Action and Freedom: Christological Controversies in the Seventh Century (Leiden: Brill, 2008), $53 \mathrm{f}$.

${ }^{50}$ P. Booth, Crisis of Empire: Doctrine and Dissent at the End of Late Antiquity (London: University of California Press, 2014), 5.

${ }^{51}$ Hovorun, Will, Action and Freedom, 55. 
Chalcedonian Christology who explicitly dealt with the issue of Christ's activities' ${ }^{52} \mathrm{He}$ notes that although this 'was not the focal point of Severus' theology', ${ }^{33}$ he did use this terminology when referring to Christ's activity. For Severus, 'Christ's energeia was primarily single: "There is only one single activity, only one single operative motion". 54 Hovorun illustrates this point with reference to Severus' comments on the Cleansing of the Leper in Matthew 8: 'While the incarnate God spoke with human tongue and said with human and clear voice to the leper: "I will, be clean" (Matthew 8:3), he showed through the effect that the voice, in keeping with the mixing worthy of God, has gone forth from the incarnate God: for the healing of the leper went together with the heard word'. ${ }^{55}$ While we do not find a similar passage quoted in the catena of Codex Zacynthius on the cleansing of the leper (Luke 5:12-14), we do find occasional references to the Greek word energeia. ${ }^{56}$ Although the majority of instances do not appear to be using the term in a technical Christological sense (in many cases it is used to describe the activity of the Holy Spirit), the term comes into particular focus in the comments on the miraculous healing of the woman who touched Jesus' garment (Luke 8:42b-48). The passage includes the

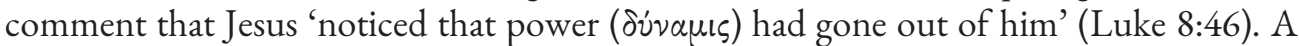
comment from Cyril notes that the Lord 'did not allow the display of divine activity

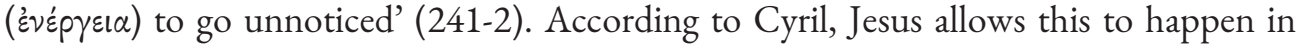
order to benefit all those 'called to grace through faith' and to provide a little encouragement to Jairus, as they travel to his home to attend to his daughter. This comment is followed immediately by another comment of Severus, who suggests that the

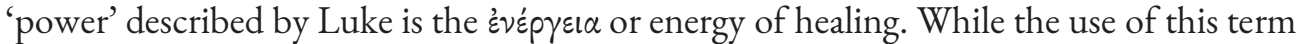
provides evidence of the way in which Severus' thinking may have influenced subsequent debate, as Hovorun argues, the fact that we see only this one example suggests that 'Monenergism' does not appear to be a dominant motif in the theological imagination of the catenist. In spite of its extensive use of material from Severus of Antioch, the contents of the catena do not appear to speak directly in to this particular debate.

\section{CONCLUSIONS}

In evaluating the theological significance of the catena, it appears that the Christological assertions characteristic of the comnmentary in Codex Zacynthius would place its compilation at the end of the sixth and the beginning of the seventh centuries. With the extensive use of the title 'Theotokos', the absence of Theodore of Mopsuestia and Theodoret of Cyrrhus, the emphasis on the unity of Christ's identity and the eschewal of

\footnotetext{
${ }^{52}$ Hovorun, Will, Action and Freedom, 16.

${ }^{53}$ Hovorun, Will, Action and Freedom, 16.

${ }^{54}$ Hovorun, Will, Action and Freedom, 16.

${ }^{55}$ Severus, Liber contra impium Grammaticum (CPG 7024), quoted in Hovorun, Will, Action and Freedom, 18.

${ }^{56}$ For example, 005-4 (Origen), 050-1 (Origen), 128-2 (Cyril of Alexandria), 220-1 (Cyril of Alexandria), 226-1 (Titus of Bostra), 241-2 (Cyril of Alexandria), 241-3 (Severus of Antioch), 2521 (Cyril of Alexandria), 293-1 (Cyril of Alexandria).
} 
the language of 'two natures', it bears the marks of the debates which had led to the various Acta of the Second Council of Constantinople. But in evaluating the contents of the scholia against subsequent Christological controversies, I have also suggested that there is little evidence that the compilers of this catena are responding to the 'Monenergist' debate of the mid-seventh century. The fact that it contains a number of comments sympathetic to the miaphysite position and makes extensive use of the writings of Severus of Antioch, describing him in the later sections of the catena as $\ddot{\alpha} \gamma 105$, suggests that the catena was compiled at a time when the Christian church was continuing to wrestle with the legacy of the Council and mediate between the Chalcedonian and anti-Chalcedonian factions. ${ }^{57}$

Such a conclusion is consistent with the 'liberal spirit' introduced in the preface to the catena with its reference to Cyril's letter to Eulogius. Although we might infer from Robert Devreesse's use of this term that the compilers of catenae were content to use material from more heterodox sources while at the same time disowning the Christological heresies which they embraced, it is evident that this does not mean that they simply ignored or avoided doctrinal questions. Luke's account of the birth of Jesus presents questions about the character of the incarnation at almost every turn. To suggest that the catena adopts a position of 'doctrinal neutrality' is not entirely accurate. While containing elements which are sympathetic to an anti-Chalcedonian position, the catena embodies ongoing Christological controversy and debate during the sixth and early seventh centuries. It represents a concerted attempt to present Luke's Christology in a way which is consistent with the legacy of Cyril of Alexandria and the deliberations of the Second Council of Constantinople in 553. At the same time, the catena only hints at the Monenergist debates which were to dominate the middle of the seventh century.

\footnotetext{
${ }^{57}$ In his study of Christology in late antiquity, Yonatan Moss notes that Severus of Antioch is often regarded as 'the founding father of the independent anti-Chalcedonian Syriac Orthodox Church' (Yonatan Moss, Incorruptible Bodies: Christology, Society and Authority in Late Antiquity [Oakland: University of California Press, 2016], 1). He argues that Severus himself was opposed to leaving the imperial state church. Although deprived of his see and exiled by Justinian in 536, the latter years of Justinian's reign were characterised by repeated efforts to find a way of accommodating the views of the Chalcedonian and anti-Chalcedonian factions.
} 
